\title{
On the Guiding Significance of Confucianism to the Study Tour
}

\author{
Liu Guorui \\ China Jiliang University \\ 258 Xueyuan Street, Higher Education Park, Jianggan District, Hangzhou
}

\begin{abstract}
The research activity is a new term that has been produced in the past ten years. It gradually evolves from activities such as ancient Chinese study tour to modern study. The ancient saying of "reading thousands of books and traveling thousands of miles" is often lingering around the ear. The ancients have already summed up the true meaning of learning. Learning should not only learn the knowledge in books, but also combine practice with what they have learned. Confucius can be regarded as the first person to study and recruit lecturers. The disciples traveled around the country and preached the disciples. The disciples followed him to visit Dutong, and realized life from the dilemma, broaden their horizons, and understand the folk customs. In 2013, the State Council first proposed the term "study travel" in the document (National Leisure Travel Program). In December 2016, the Ministry of Education and other 11 departments jointly issued the "Opinions on Promoting the Study of Primary and Secondary School Students", including the admission of research and teaching activities. Since then, "Study Travel" has officially entered national vision and has been talked about by many educators. Confucianism is one of the 100 masterpieces of the pre-Qin philosophers. His thoughts are inclusive and have a profound influence on China, Southeast Asia and the world. This thesis combines the Confucian core thought "the doctrine of the mean" to understand the guiding significance of Confucianism for the study tour under the condition of Confucianism and justice.
\end{abstract}

Keywords-Research travel; Justice and benefits; The doctrine of the mean

\section{THE GUIDING SignificANCE OF CONFUCIAN VIEW OF CONFUCIANISM}

\section{A. Confucian School of Justice and Benefits in the Guidance of Research Industry}

Confucian concept of justice and benefit is produced under the condition that the self-sufficient natural economy is the main body and the feudal hierarchy system is the basic social system, but it still has a strong guiding significance in the contemporary. Among them, the idea of "unification of righteousness and interests", "seeing the righteousness of justice", "profiting by righteousness", "being righteous and profiting", and "sacrificing the body" is still shining. As the ideological foundation of Chinese moral behavior, the Confucian concept of righteousness and benefit has nurtured generations of talented people with noble moral personality and made outstanding contributions to the "state of ceremonies" of the Chinese nation. In today's global economy, the market economy continues to develop, and the vast market has created a group of successful people. Behind the success, it constantly maps out some problems existing in the current society. People are uneasy and pay attention to "heavier interests and light justice". Some people even use many unfair means in pursuit of interests. The contradiction between morality and interests has always been one of the main contradictions in society. Some people completely oppose the two and over-emphasize the "interest-driven", so in order to pursue the interests, they can use whatever means. Confucius advocated "making justice by righteousness" and emphasizing "seeking righteousness and benefiting" ("The Analects of Confucius and Constitutional Questions"). In Confucius' view, there is nothing wrong with pursuing interests itself, but one's pursuit of interests must be moral and not moral. Interests cannot be pursued, that is, "unrighteousness is rich and expensive, and like me is a cloud" ("The Analects of Confucius"). Mencius inherited the views of Confucius on the concept of justice and benefit, and believed that people should pursue moral interests. Obviously, the "study travel" as a new type of market is inevitably produced fierce competition. In the future, there will be many companies entering this market, but "Study Travel" is a part of the education plan for primary and secondary school students, and its status is very important. The issue of education is always a hot issue in society. The education of the next generation of "juvenile is strong and strong" is always a sacred task. The three views of educators often influence the value of the next generation, so establish the correct The three views are an urgent task. Confucius believes that the pursuit of interests is the nature of human beings, and also the objective needs of human beings. "Diet and men, the great desires of human beings, the death of poverty, the great evils of human beings." ("Book of Rites, Li Yun") At the same time, Confucius emphasized "seeing the righteousness and benefiting". On the basis of Confucius and Mencius, Xunzi proposed "to benefit the righteousness" ("Xunzi•On the Theory"). Xunzi believes that "making things by righteousness, knowing what to do" means that only doing things with "righteousness" can be said to be the best way to make money. This has a strong guiding significance for the "study travel" industry. As a part of the market economy, the "study travel" industry chain must be based on profit, but at the same time, because of the particularity of the industry in which it is located, education is the focus. The more critical part. As a part of the education of primary and secondary school students, "study travel" is extremely important in the industry. There is nothing wrong with pursuing economic benefits. However, as part of the education industry, the "study travel" industry should uphold the Confucian idea of "profit-making", putting primary and secondary school 
education first, and improving the overall quality of primary and secondary school students. On the basis of one's important task, on the basis of the educational responsibility that should be undertaken by itself, we must pursue the moral interests, combine the "righteousness" and the "profit" in the market activities, and seek profit without loss of meaning, ensuring the healthy and orderly market. development of.

\section{B. Confucian School of Justice and Benefits in the Teaching of Teaching}

In the education link involving the specific "study travel" of primary and secondary school students, the Confucian concept of righteousness and benefit is also targeted, and it also has a strong guiding significance. Ancient China has always emphasized the education of human beings. "The body is affected by the parents, who dare not harm, and the beginning of filial piety" ("Xiao Jing•Cai Zong Ming Yi Zhang") is to warn us to cherish the body and cherish life. Healthy body and mind are our people doing things. At the beginning, it is also the source of filial piety. The Confucian view of "before justice and benefit" put forward the guiding significance not only for the research industry in the market economy, but also for the application of human relations. In dealing with various human relations in life, "first benefit and then righteousness" or "first righteousness and benefit", Confucianism tells us that "first sense and then benefit" will pursue morality as the highest ideal goal and ultimate goal. Xunzi will carry forward this point of view, that is, "the righteous after the benefit of the glory, the first benefit of the righteous humiliation" ("Xunzi•honor and disgrace"), in life, people should live with morality as the standard, and moral things can be paid Implementation, things that are not moral, even if the country is as strong as it should be tempted and shameful. Honoring parents should do their best; treating friends with words and trust; treating elders with respect and addition... This is the foundation of human beings and the principle of life. For more than 5,000 years of Chinese history, from ancient times to the present, whether it is in a peaceful era or at a critical juncture, the Chinese nation always puts "righteousness" in the first place in front of the righteousness. This is precisely the long history of the Chinese nation. The reason for the downside. Mencius once said: "Birth, what I want, righteousness, and what I want, the two can't have both, and those who give up the life and take the righteousness." ("Mencius on the confession") People's life is in No matter what choices are made, nothing is material pursuit and spiritual pursuit. The concept of justice and benefit has a guiding role in the shaping of the three views and the choices of life. The reason why people are human is to fulfill their obligations and defend their dignity, not to pursue their own self-interest. In the educational activities of "Study and Study Travel", the idea of "being a righteousness and benefiting" and "taking a life-seeking righteousness" is interspersed among them, which makes it easier for primary and secondary school students to intuitively understand the principles of a good life and the principle of being human, and to dress and eat. To become a family, to benefit the society, and to serve the motherland, we should take the word "righteousness" first, establish a correct three-view, and use moral means to realize our own ideals of life.

\section{THE GUIDING SIGNIFICANCE OF II'S DOCTRINE OF THE MEAN}

\section{A. Mean's Way in the Guidance of the Research Industry}

The Confucian concept of righteousness and righteousness advocates combining "righteousness" with "profit" and morally chasing interests, thus achieving a dynamic balance, which is also in line with the Confucian "moderate" thought. On the basis of establishing a correct value orientation, how to achieve a balance between the two? To pursue "profit", we must first grasp "righteousness", and the mean is based on "righteousness". "The Doctrine of the Mean" says: "The righteous, Yi also." That is the right reason or move. Han $\mathrm{Yu}$ said in the "Original Road": "The meaning of fraternity is good, and the righteousness is right." "The Doctrine of the Mean" has always been the core concept of Chinese traditional culture, and its wisdom has always been respected by the sages of the past. Unfortunately, in the past 100 years, due to the impact of Western scientific and technological development, this outstanding traditional cultural thought has been misunderstood by people. Especially today, people are mad at the desires of the world, and the secular people understand it as the "wall philosophy" of the wall-mounted school, the ambiguous and muddy, the old good man who is free to compromise, the fact that they don't take the lead, the principle, the right and the left, the slick The way of life and so on. Others are out of the meaning of the words "In" and "Yong Yong ":" in" is understood as "the middle route" and "Yong" is understood as "the mediocrity". The true doctrine of the golden mean is a kind of wisdom in the world. The word "the doctrine of the mean" was proposed by Confucius and Mencius. The son said: "The virtue of the mean is also the virtue, and it is almost! The people can live for a long time." ("The Analects of Confucius" "I know what you know? I don't know. There are cowards who ask me, empty and empty. I squat at both ends" ("The Analects of Confucius"). The doctrine of the doctrine refers to the attitude of being impartial and compromised, that is, "the golden mean is also the virtue, and it is almost the same." The doctrine of the mean is the fundamental theory of success in life, success in business, and health in life. On the issue of grasping "righteousness", the Zhongyong believes that it is not easy to be biased. It means that life does not deviate and does not change its goals and opinions. This is a consistent way to success.ConfuciusThere is a saying: "The virtue of the middle is also the virtue, it is almost! The people are fresh for a long time." Zhongyong can also be understood as the middle finger is good, mediocre use, that is, a person should have a skill, become a useful talent, also refers to people should In his position, he sticks to his position and assumes his responsibilities. In the "study travel" industry, whether it is macro industry development, enterprise prospects, or micro project construction, enterprise management can be based on the "moderation of the mean". Being a person, doing things consistently, seriously and responsibly, and improving yourself in constant development, in order to gain the recognition and trust of customers, to gain a foothold in the industry, can we talk about the long-term development of the industry, so that it is considered to be in a moral pursuit of interests, So to truly grasp the dynamic balance between "righteousness" and "profit". 


\section{B. The Doctrine of the Mean in the Guidance of Research Education}

"The Doctrine of the Mean" is based on the theory of "harmony between man and nature". The concept of "harmony between man and nature" originated from Lao Zhuang and Lao Tzu. "People and law, earth and law, heaven and earth, and Taoism are natural." ("The Tao Te Ching Twenty-five Chapters") Zhuang Zikai: "Someone, the sky is also; there are days, and the heavens are also. People can't have heaven, sex is also. The saints are suddenly lost and end up." In the rapid development of the current society, the problem of environmental pollution can no longer be ignored, and the theory of the community of human destiny is constantly expanding. There is only one earth, and it is imperative to protect the environment of our children and grandchildren. The mediocrity of "the combination of heaven and man" can be understood as loving nature and loving life. Combining the natural scenery in "Study Travel", we can better cultivate the love of nature between primary and secondary school students, understand the language of all life, feel the existence of life from time to time, blend with the melody of nature, and be able to obtain each other's life. The trust and harmony coexist, coexist harmoniously with nature, the combination of human and material, material and material is ingeniously perfect, and stimulates the desire for environmental protection. The socalled "green mountains and green water is Jinshan Yinshan". Similarly, "The Doctrine of the Mean" has a profound influence on personality cultivation. The moderates believe that everything is yin and yang. In this kind of relative, it is necessary for the two sides to transform each other and move to achieve a dynamic balance. This is the wisdom of "middle", that is, it is too late. "Over" and "inferior" are the two extremes of the development of things. The golden mean rejects both, and advocates unbiasedness and duality. Confucius praised the method of doing things as "hidden and good, and held both ends, using it in the people" (Chapter 6 of The Doctrine of the Mean). And his method of resolving contradictions is to "execute dual use" and "harmony and difference." He opposed the use of two extreme methods and means to deal with things. The doctrine also warns people that they need to maintain peace in the middle. If they lose their Zhongzheng and peace, they must be happy, angry, sad, and happy. It is only fun to rule the anger, and the way to treat the ritual is to be respectful. As long as you maintain a respectful or awe-inspiring heart, Zhongzheng and peace will last forever, and human health will be guaranteed. The golden mean is precious in self-cultivation, Confucius said: "Gentlemen don't pay, they don't complain, they don't greed, they don't greedy, they don't arrogant, they don't arrogate." ("The Analects of Confucius") This is the gentleman's five beauty, which is the virtue of a gentleman. On how to realize the doctrine of the mean, Confucius put forward two ways of "loyalty" and "forgiveness", that is, "you want to stand and stand up, you want to reach people and reach people", "do not do what you want to do." These theories all show that you want to do things first and you must first cultivate yourself. In combination with "study travel", you can also admonish students not to be arrogant, to maintain neutrality between desire and reason, not to be influenced by foreign objects, to be rational, and to do everything right.

\section{CONCLUSION}

As a new educational model, "Study Travel" was widely controversial at the time of its submission. On the one hand, it felt that education no longer sticks to the rules and regulations, and truly takes a solid foundation under the teaching of "Reading thousands of books and traveling thousands of miles". One step, on the other hand, has questioned whether it can truly combine the "tour" and "learning". This road is bound to be difficult and difficult, and it requires the unremitting efforts of the society and the educators. The author hopes that the educators engaged in this industry can achieve "seeing the righteousness", constantly improve themselves, and truly provoke the burden of "study travel", and hope that the majority of primary and secondary school students can truly achieve "a journey of a thousand miles." Beginning with the footsteps, it has accumulated thousands of miles, inheriting the traditional culture of China, and becoming the pillar of society and the country, allowing the "state of etiquette" to last for thousands of years. Because the author's qualifications are still shallow, only the students are limited, and I hope that the vast number of people can be enlightened.

\section{REFERENCES}

[1] He Zhiyan. On the Educational Management Function of Confucianism[A]. Education in the Times: (Educational Edition), 2008.

[2] Gao Dewen. The Realistic Enlightenment of Confucian View of Righteousness and Interest [A]. Journal of Tube, 2001.

[3] Liu Yongpeng. On the main purpose of the Confucian concept of justice and benefit [A]. Journal of Tube, 2006.

[4] Luo Yong. Feeling the Doctrine of the Mean [B]. Reading and Computing (Teacher Edition); Quality Education Forum, 2014.

[5] Tan Xiaofang. Gentleman depends on the doctrine of the "Leadership Strategy in the Doctrine of the Mean" [A]. Home, 2012. 